Magdalena Rutkowska-Sowa ${ }^{1}$

\title{
TRANSFER WYNIKÓW PRACOWNICZEJ TWÓRCZOŚCI INTELEKTUALNEJ Z UCZELNI DO GOSPODARKI W NOWELIZACJI USTAWY - PRAWO O SZKOLNICTWIE WYŻSZYM
}

\section{Uwagi ogólne}

W XXI wieku jesteśmy świadkami zmieniającej się roli uczelni w społeczeństwie. Polskie szkoły wyższe, dotychczas funkcjonujące w oparciu o model humboldtowski, w którym najważniejszą misją uniwersytetu jest prowadzenie badań i dydaktyki, stają przed wyzwaniem dostosowania się do realiów gospodarki opartej na wiedzy. Nowym określeniem charakteryzującym działalność uniwersytetu staje się przymiotnik ,przedsiębiorczy”. Uczelnie wprowadzają do swojej misji podejście biznesowe, w zarządzaniu posiadanymi zasobami, w tym własnością intelektualną, kierują się kryteriami rynkowymi. Ich celem staje się skomercjalizowanie wyników badań naukowych, wdrożenie wiedzy do działalności gospodarczej. Zmiany zachodzące w systemie nauki i szkolnictwa wyższego nie pozostają bez wpływu na unormowania prawne. Kluczową regulację we wskazanym zakresie zawiera obecnie ustawa z dnia 27 lipca 2005 r. - Prawo o szkolnictwie wyższym, ${ }^{2} \mathrm{w}$ brzmieniu nadanym przez ustawę z dnia 11 lipca 2014 r. o zmianie ustawy - Prawo o szkolnictwie wyższym oraz niektórych innych ustaw. ${ }^{3}$

\section{Komercjalizacja wyników badań naukowych i prac rozwojowych w ustawie - Prawo o szkolnictwie wyższym}

Jednym z 4 głównych założeń ostatniej zmiany ustawy - Prawo o szkolnictwie wyższym stało się jej doprecyzowanie w oparciu o doświadczenia z wdrażania no-

Doktor nauk prawnych, Katedra Prawa Własności Intelektualnej Wydziału Prawa Uniwersytetu w Białymstoku.

Tekst jedn. Dz.U. z 2012 r. poz. 572 z późn zm., dalej jako: pr.sz.w.

Dz.U. z 2014 r. poz.1198, dalej jako: nowelizacja z dnia 11 lipca 2014 r. 
welizacji przeprowadzonej w $2011 \mathrm{r}^{4} \mathrm{~W}$ projekcie założeń ustawy nie przedstawiono jednak całościowej, spójnej wizji kształtowania modelu komercjalizacji wyników badań naukowych i prac rozwojowych (dalej jako: wyniki B+R). Autorzy w uzasadnieniu ograniczyli się wyłącznie do uwagi, iż jedną z bolączek polskiej gospodarki jest niezadowalający poziom wykorzystywania w praktyce przez przedsiębiorstwa wyników $\mathrm{B}+\mathrm{R}$, czego skutkiem jest niska innowacyjność polskich przedsiębiorstw. Ocenili, że projektowana ustawa, poprzez zagwarantowanie naukowcom praw własności intelektualnej, wprowadzi znaczący impuls do aktywnych działań w zakresie komercjalizacji wyników prowadzonych przez nich badań. ${ }^{5}$

Brak strategii miał znaczny wpływ na dalszy przebieg procesu legislacyjnego. Prace nad nowelizacją były niezmiernie dynamiczne. W kolejnych projektach prezentowano bez uzasadnienia zasadniczo różniące się koncepcje. Najbardziej wyrazistym przykładem zmienności założeń była debata, która dotyczyła tzw. „uwłaszczenia naukowców”. W dniu 15 marca 2013 r. w projekcie założeń projektu ustawy MNiSW po raz pierwszy przedstawiło zmianę systemową polegającą na zagwarantowaniu pracownikom uczelni praw do tworzonych przez nich dóbr własności intelektualnej i zapewnieniu szkołom wyższym udziału $\mathrm{w}$ dochodach $\mathrm{z}$ tytułu komercjalizacji wyników B+R. ${ }^{6}$ Propozycje właściwych unormowań prawnych zawarto $\mathrm{w}$ projekcie z dnia 16 lipca 2013 r. ${ }^{7}$ Spotkał się on z powszechną krytyką. ${ }^{8}$ A. Szewc ocenił jednoznacznie, że autorzy projektu dokonują wyłączenia ochrony własności intelektualnej w obszarze nauki spod ogólnych zasad prawa własności intelektualnej, tym samym cofają nasz system prawny o ponad 100 lat. ${ }^{9}$ Pomimo licznych negatywnych stanowisk doktryny oraz przedstawicieli środowiska nauki koncepcja uwłaszczenia naukowców została utrzymana w kolejnym projekcie z dnia 23 października 2013 r., ${ }^{10}$ a następnie - po doprecyzowaniu - zawarta w projekcie

Rządowy projekt ustawy o zmianie ustawy - Prawo o szkolnictwie wyższym oraz niektórych innych ustaw z dnia 17 stycznia 2014 r., Druk nr 2085 http://www.sejm.gov.pl/sejm7.nsf/druk.xsp?documentld=32CE96E4BB128ADCC1257C6E00341EAB5, dalej jako: Projekt rządowy z dnia 17 stycznia 2014 r. Projekt rządowy z dnia 17 stycznia 2014 r., s. 3.

Pkt 2.4. Projekt założeń projektu ustawy o zmianie ustawy - Prawo o szkolnictwie wyższym oraz o zmianie innych ustaw z dnia 15 marca 2013 r., http://legislacja.rcl.gov.pl/docs//2/170167/170171/170172/dokument14159. pdf (data dostępu: 30.04.2015 r.), s. 15.

Art. 1 pkt 52 Projektu z dnia 16 lipca 2013 r. Ustawa z dnia o zmianie ustawy - Prawo o szkolnictwie wyższym oraz o zmianie niektórych innych ustaw, http://legislacja.rcl.gov.pl/docs//2/170167/170171/170172/dokument79857.pdf (data dostępu: 30.04.2015 r.).

8 S. Soltysiński, Przyczynek do dyskusji o naprawie poziomu innowacyjności, Kwartalnik „Urząd Patentowy Rzeczypospolitej Polskiej” 2013, nr 5, s. 39; Stowarzyszenie 500 Innovators, Ocena skutków art. 1 pkt 52 ), art. 7 pkt 4) oraz art. 8 pkt 4 projektu ustawy o zmianie ustawy - prawo o szkolnictwie wyższym oraz o zmianie niektórych innych ustaw, http://legislacja.rcl.gov.pl/docs//2/170167/170171/170174/dokument90101.pdf (data dostępu: 30.04.2015 r.), s. 17; Stanowisko KRASP z dnia 20 sierpnia 2013 r. zawierające uwagi do Projektu ustawy o zmianie ustawy - Prawo o szkolnictwie wyższym oraz o zmianie niektórych innych ustaw z 16 lipca 2013 r., http://www. krasp.org.pl/pl/uchwaly_opinie_komentarze/uchwaly_opinie_komentarze (data dostępu: 30.04.2015 r.), s. 10. A. Szewc, Uwagi do projektu ustawy o zmianie ustawy prawo o szkolnictwie wyższym, dokument z dnia 24 lipca 2013 r., http://www.krasp.org.pl/pl/uchwaly_opinie_komentarze/uchwaly_opinie_komentarze (data dostępu: 30.04.2015 r.).

art. 1 pkt 58 Projektu z dnia 23 października 2013 r. Ustawa z dnia o zmianie ustawy - Prawo o szkolnictwie wyższym oraz o zmianie niektórych innych ustaw, http://www.bip.nauka.gov.pl/g2/oryginal/2013_10/c4f5656fdddb93e9360e98fe0ad427a4.pdf (data dostępu: 30.04.2015 r.). 
Transfer wyników pracowniczej twórczości intelektualnej z uczelni do gospodarki...

rządowym z dnia 17 stycznia 2014 r. Dopiero w toku prac legislacyjnych w Sejmie odstąpiono od koncepcji przekazania praw własności intelektualnej pracownikom uczelni. W dniu 28 maja 2014 r. po pierwszym czytaniu Podkomisja stała ds. nauki i szkolnictwa wyższego zaproponowała wprowadzenie do tekstu ustawy pięciu przepisów - art. 86d-86h, które nie zakładały pełnego uwłaszczenia naukowców, jak również nie przyznawały uczelniom publicznym prawa pierwokupu lub pierwszeństwa w nabyciu praw własności intelektualnej. ${ }^{11}$ Pomimo tak zasadniczych zmian, nowe zapisy legislacyjne nie zostały opatrzone komentarzem. Po niespełna dwóch miesiącach, 11 lipca 2014 r. Sejm uchwalił projekt ustawy o zmianie ustawy - Prawo o szkolnictwie wyższym oraz niektórych innych ustaw. Przepisy weszły w życie z dniem 1 października 2014 r.

Należy podkreślić, że pomimo swojej doniosłości unormowania dotyczące budowania polskiego modelu transferu wyników B+R z uczelni do gospodarki wciąż nie spotkały się z pogłębionym komentarzem doktryny prawa. Nie były również przedmiotem rozstrzygnięć judykatury. Niezależnie jednak kształtować zaczęła się praktyka stosowania przepisów ustawy - Prawo o szkolnictwie wyższym. W efekcie w coraz większym stopniu zauważalny staje się podział na uczelnie odnoszące sukcesy w zakresie komercjalizacji wyników B+R oraz na szkoły wyższe, które wciąż nie mają doświadczenia, a nawet wypracowanych procedur we wskazanym zakresie. Rozważenia wymaga więc, czy znowelizowane przepisy art. 86-86i p.s.w. zdołają zmienić istniejący stan rzeczy.

\section{Definicja komercjalizacji wyników $B+R$}

W wyniku zmian wprowadzonych przez nowelizację z dnia 11 lipca 2014 r. do słowniczka ustawy - Prawo o szkolnictwie wyższym wprowadzono definicje pojęć „komercjalizacja bezpośrednia” i ,pośrednia”. Komercjalizacja bezpośrednia oznacza sprzedaż wyników $\mathrm{B}+\mathrm{R}$ lub know-how związanego z tymi wynikami albo oddawanie do używania tych wyników lub know-how, w szczególności na podstawie umowy licencyjnej, najmu oraz dzierżawy (art. 2 pkt 35 p.s.w.). Przez komercjalizację pośrednią należy natomiast rozumieć obejmowanie lub nabywanie udziałów lub akcji w spółkach w celu wdrożenia lub przygotowania do wdrożenia wyników $\mathrm{B}+\mathrm{R}$ lub know-how związanego z tymi wynikami (art. 2 pkt 36 p.s.w.). W definiensie obu pojęć pojawia się odniesienie do „,badań naukowych” i ,prac rozwojowych”, ustawa - Prawo o szkolnictwie wyższym nie zawiera ich definicji legalnych. Powinny być więc rozumiane zgodnie z regulacją art. 2 pkt 3-4 u.z.f.n. ${ }^{12}$ Należy przy tym zaznaczyć, że z dniem 25 maja 2015 r. wejdzie w życie nowe brzmienie wska-

\footnotetext{
11 Art.1 pkt 58 Projektu z dnia 28 maja 2014 r. - sprawozdanie Podkomisji stałej ds. nauki i szkolnictwa wyższego o rządowym projekcie Ustawy o zmianie ustawy - Prawo o szkolnictwie wyższym oraz niektórych innych ustaw, http://www.sejm.gov.pl/SejmSearch/ADDL.aspx?SelectResult (data dostępu: 30.04 .2015 r.). 
zanych przepisów, zarówno w przypadku badań naukowych, jak i prac rozwojowych zawierające odniesienie do potencjału komercyjnego wyników B+R. ${ }^{13}$

\section{Regulaminy zarządzania prawami własności intelektualnej}

Podstawę kształtowania wewnętrznej polityki szkoły wyższej w zakresie komercjalizacji wyników $\mathrm{B}+\mathrm{R}$ stanowią regulaminy zarządzania własnością intelektualną. Ich uchwalenie należy obecnie do obowiązków uczelni. Prawodawca poszerzył zakres przedmiotowy tego rodzaju regulacji, jednocześnie wprowadził rozróżnienie dotyczące obligatoryjnej treści regulaminów obowiązujących w uczelniach publicznych i prywatnych. Zgodnie $\mathrm{z}$ art. $86 \mathrm{c}$ ust. 1 pkt 1 p.s.w. regulamin powinien zawierać postanowienia dotyczące $\mathrm{w}$ szczególności:

- praw i obowiązków uczelni, pracowników oraz studentów i doktorantów w zakresie ochrony i korzystania z praw własności intelektualnej;

- zasad wynagradzania twórców;

- zasad i procedur komercjalizacji;

- zasad korzystania z majątku uczelni wykorzystywanego do komercjalizacji oraz świadczenia usług naukowo-badawczych.

Ponadto, uczelnie publiczne w regulaminie powinny określić zasady:

- podziału środków uzyskanych z komercjalizacji między twórcą będącym pracownikiem a uczelnią;

- zasady i tryb przekazywania uczelni przez pracownika, studenta lub doktoranta tej uczelni informacji: o wynikach $\mathrm{B}+\mathrm{R}$ oraz o know-how, związanym z tymi wynikami, o uzyskanych przez pracownika środkach z komercjalizacji oraz zasady i tryb przekazywania przez pracownika przysługujących uczelni części środków uzyskanych z komercjalizacji;

- zasady i tryb przekazywania pracownikowi przez uczelnię informacji o decyzjach w sprawie komercjalizacji lub niekomercjalizacji oraz zasady i tryb przekazywania przez uczelnię przysługujących pracownikowi części środków uzyskanych z komercjalizacji.

Na mocy art. 46 pkt 1 nowelizacji z dnia 11 lipca 2014 r. uczelnie zostały zobowiązane dostosować treść regulaminów do nowych wymogów do końca marca 2015 r. Pomimo że ustawodawca na wprowadzenie do regulaminów zagadnień wynikających z art. 86c p.s.w. przewidział półroczny termin, to na większości uczelni były one uchwalane dopiero w ostatnim momencie. Jednymi z pierwszych, które znowelizowały obowiązujące regulaminy były: Uniwersytet Medycznym w Lubli- 
nie (17 grudnia 2014 r.), ${ }^{14}$ czy Uniwersytet Warmińsko-Mazurski w Olsztynie (30 stycznia 2015 r.). ${ }^{15} \mathrm{~W}$ większości szkoły wyższe czekały jednak na wytyczne, których opracowanie uprzednio zapowiadało MNiSW oraz UPRP. Dopiero 26 stycznia 2015 r. pierwszą propozycję przedstawiło NCBiR, ${ }^{16}$ przy czym w komentarzu do preambuły regulaminu autorzy zastrzegli, że jego treść ma charakter ramowy i nie uwzględnia specyfiki uczelni i jej schematu organizacyjnego.

Można przewidywać, że znaczenie regulaminów będzie wzrastać - nie tylko w wymiarze krajowym. Posiadanie wewnętrznej regulacji w zakresie zarządzania własnością intelektualną stanowi jedno z zaleceń Komisji Europejskiej. ${ }^{17}$ Wymóg posiadania regulaminu zarządzania własnością intelektualną w szczególny sposób dotyczy beneficjentów programu Horyzont 2020, wynika m.in. z art. 23a Modelowej Umowy Grantowej. ${ }^{18}$

\section{Procedura rozpatrywania zgłoszenia pracowniczego wyniku pracy intelektualnej w uczelniach publicznych}

Nowy, wyznaczony ustawowo zakres przedmiotowy i podmiotowy regulaminów należy interpretować w związku z dalszymi przepisami ustawy - Prawo o szkolnictwie wyższym. Wskutek nowelizacji z dnia 11 lipca 2014 r. do treści ustawy dodano przepisy art. 86d-86h p.s.w., w których prawodawca odniósł się do procedury rozpatrywania wyników pracowniczej twórczości intelektualnej w uczelniach publicznych. Zgodnie z art. 86d p.s.w. w przypadku zgłoszenia przez pracownika wyniku w postaci:

1) badań naukowych będących wynalazkiem, wzorem użytkowym, wzorem przemysłowym lub topografią układu scalonego, wyhodowaną albo odkrytą i wyprowadzoną odmianą rośliny,

2) prac rozwojowych powstałych w ramach wykonywania obowiązków ze stosunku pracy, uczelnia - w okresie trzech miesięcy od dnia otrzymania od

14 Regulamin zarządzania prawami własności intelektualnej w Uniwersytecie Medycznym w Lublinie Załącznik do Uchwały Nr CCCLIV/2014 Senatu UM w Lublinie z dnia 17 grudnia 2014 r., http://www.bip.umlub.pl/wewnetrzne-akty-prawne/uchwaly-senatu/page,2.html (data dostępu: 30.04.2015 r.).

15 Regulamin zarządzania prawami autorskimi i prawami pokrewnymi oraz prawami własności przemysłowej oraz zasad komercjalizacji w Uniwersytecie Warmińsko-Mazurskim w Olsztynie Załącznik do Uchwały Nr 661 z dnia 30 stycznia 2015 r., http://www.uwm.edu.pl/ciitt/wp-content/uploads/2015/02/27.01.2015-Tekst-ujednolicony-Regulaminu-IP.pdf (data dostępu: 30.04.2015 r.).

16 Wzór regulaminu zarządzania prawami własności intelektualnej, http://bridge.gov.pl/aktualnosc/pokaz/regulamin-zarzadzania-prawami-wlasnosci-intelektualnej-okresla-komercjalizacje-badan-naukowych/ (data dostępu: 30.04.2015 r.).

17 Pkt 1-2 Załącznik I do Zaleceń KE z dnia 10 kwietnia 2008 r. w sprawie zarządzania własnością intelektualną w ramach działań związanych z transferem wiedzy oraz Kodeks postępowania dla uczelni wyższych i innych publicznych instytucji badawczych (notyfikowana jako dokument nr C(2008) 1329) (Tekst mający znaczenie dla EOG), Dz. Urz. UE L 146 z dnia 5 czerwca 2008 r., s. 21.

18 General Multi-Beneficiary Model Grant Agreement For The Horizon 2020 Programme1 (H2020 General MGA - Multi), http://ec.europa.eu/research/participants/data/ref/h2020/mga/gga/h2020-mga-gga-multi_en.pdf (data dostępu: 30.04 .2015 r.). 
pracownika informacji o ich stworzeniu - zobowiązana jest podjąć decyzję o komercjalizacji albo niekomercjalizacji.

Należy podkreślić, że przepisy ustawy nie wyznaczają procedury rozpatrywania zgłoszenia pracowniczego wyniku pracy intelektualnej. W art. 86e p.s.w. prawodawca określił wyłącznie obowiązek uczelni publicznej do podjęcia decyzji w sprawie komercjalizacji. W przypadku powzięcia decyzji o niekomercjalizacji albo też po bezskutecznym upływie trzymiesięcznego terminu, uczelnia jest zobowiązana, w terminie 30 dni, do złożenia pracownikowi oferty zawarcia bezwarunkowej i odpłatnej umowy o przeniesienie praw do wyników $\mathrm{B}+\mathrm{R}$ oraz know-how związanego z tymi wynikami, łącznie z informacjami, utworami wraz z własnością nośników, na których utwory te utrwalono i doświadczeniami technicznymi, przekazanymi uprzednio przez pracownika. Artykuł 86e ust. 2 p.s.w. precyzuje, że umowa powinna zostać zawarta w formie pisemnej, pod rygorem nieważności. Ponadto, ustawodawca przyjmuje, że wynagrodzenie przysługujące uczelni publicznej za przeniesienie praw nie może być wyższe niż $10 \%$ minimalnego wynagrodzenia za pracę, obowiązującego na dzień zawarcia umowy. W 2015 r. nie może więc ono przekroczyć 175 zł. ${ }^{19}$ Jest to jednocześnie maksymalna wysokość wynagrodzenia przysługującego uczelni z tytułu przeniesienia praw do wyników $\mathrm{B}+\mathrm{R}$. Zgodnie z wykładnią dokonaną przez MNiSW nie istnieje potrzeba dokonywania dodatkowej wyceny praw przenoszonych przez uczelnię publiczną na pracownika, bowiem pozostaje ona bez związku z wysokością wynagrodzenia przysługującego uczelni $\mathrm{z}$ tytułu przeniesienia praw. Uczelnia zobowiązana jest jednak zapłacić podatek dochodowy przyjmując za podstawę opodatkowania wysokość wynagrodzenia określonego $\mathrm{w}$ umowie. ${ }^{20}$

W przypadku nieprzyjęcia przez pracownika oferty zawarcia umowy, prawa do wyników $\mathrm{B}+\mathrm{R}$ oraz know-how związanego z tymi wynikami, łącznie $\mathrm{z}$ informacjami, utworami wraz z własnością nośników, na których utwory te utrwalono i doświadczeniami technicznymi przekazanymi uprzednio przez pracownika, przysługują uczelni publicznej. Od tego momentu może ona rozporządzać prawami i korzystać w wyników $\mathrm{B}+\mathrm{R}$ na zasadach ogólnych. ${ }^{21}$

Powyższe reguły postępowania ze zgłoszeniem wyniku pracowniczej twórczości intelektualnej nie dotyczą przypadków, gdy badania naukowe lub prace rozwojowe:

- stanowią badania lub prace zlecone;

19 Rozporządzenie Rady Ministrów z dnia 11 września 2014 r. w sprawie wysokości minimalnego wynagrodzenia za pracę w 2015 r. (Dz.U. z 2014 r. poz. 1220). patentmen.org.pl/wordpress/wp-content/uploads/2014/11/odp_z_MNiSW.pdf (data dostępu: 30.04.2015 r.), s. 4. 
Transfer wyników pracowniczej twórczości intelektualnej z uczelni do gospodarki...

- były prowadzone z wykorzystaniem środków finansowych, których zasady przyznawania lub wykorzystywania określają odmienny niż w ustawie sposób dysponowania wynikami B+R oraz know-how związanym z tymi wynikami (art. 86e ust. 4 p.s.w.)

Warto podkreślić, że ustawa - Prawo o szkolnictwie wyższym nie zawiera przepisów określających przebieg procesu komercjalizacji sensu stricto, rozumianego jako zawieranie umów z podmiotami gospodarczymi, czy zakładanie nowych spółek. Zgodnie z art. 86i p.s.w. w sprawach nieuregulowanych stosuje się przepisy ustawy z dnia 4 lutego 1994 r. o prawie autorskim i prawach pokrewnych, ${ }^{22}$ ustawy z dnia 30 czerwca 2000 r. - Prawo własności przemysłowej ${ }^{23}$ oraz ustawy z dnia 26 czerwca 2003 r. o ochronie prawnej odmian roślin. ${ }^{24}$

Należy zauważyć, że w istocie ustawodawca motywuje uczelnie jedynie do podjęcia decyzji o komercjalizacji bądź niekomercjalizacji, co nie jest jednak tożsame z wymogiem rozpoczęcia działań, których efektem będzie skomercjalizowanie wyniku badań. Wydaje się, że wprowadzenie ograniczenia w postaci nałożenia na uczelnie publiczne obowiązku podjęcia decyzji o komercjalizacji w okresie trzech miesięcy od dnia otrzymania od pracownika informacji o stworzeniu wyniku pracy intelektualnej można oceniać jako próbę zmobilizowania szkół wyższych do szybszego określania potencjału komercjalizacyjnego posiadanych wyników $B+R$, a jednocześnie formę zabezpieczenia interesów pracowników - ochrony przed zaprzepaszczaniem wyników ich działalności naukowej. Pozostaje przy tym wyrazić nadzieję, że uczelnie faktycznie będą podejmowały merytoryczne decyzje, a w przypadku braku perspektyw urynkowienia posiadanych zasobów umożliwią działania twórcom. Należy bowiem zauważyć, że w praktyce zapis art. 86e p.s.w. nie wyklucza podjęcia przez uczelnię odgórnej decyzji o komercjalizowaniu wszelkich wyników $\mathrm{B}+\mathrm{R}$, a następnie tak jak w dotychczasowy sposób - w niedookreślonym czasie - podejmowania prób ich komercjalizacji. Ustawodawca nie przewidział sankcji za niezawarcie z pracownikiem umowy o przeniesienie praw, czy za niezrealizowanie komercjalizacji pomimo uprzedniej decyzji uczelni publicznej o komercjalizacji. MNiSW zapowiedziało jedynie, iż ,będzie monitorować działalność uczelni w zakresie komercjalizacji, w szczególności w celu oceny, czy uczelnie nie blokują lub ograniczają procesu komercjalizacji dokonywanej przez pracowników". ${ }^{25}$ Kolejną kontrolę w przedmiocie działalności szkół wyższych w zakresie ochrony ich własności intelektualnej oraz upowszechniania nauki przeprowadza obecnie także delegatura NIK w Kielcach. ${ }^{26}$

Tekst jedn. Dz.U. z 2006 r. Nr 90, poz. 631, z późn. zm.

Tekst jedn. Dz.U. z 2013 r. poz. 1410.

Dz.U. z 2003 r. Nr 137, poz. 1300, z późn. zm.

Odpowiedź na pismo Rady Rzeczników Patentowych Szkół Wyższych..., op. cit., s. 6.

Plan pracy Najwyższej Izby Kontroli na 2015 rok, Nr kontroli P/14/084, https://www.nik.gov.pl/plik/id,7642.pdf (data dostępu: 30.04 .2015 r.), s. 39. 


\section{Obowiązki pracownika uczelni publicznej w zakresie komercjalizacji wyników $B+R$}

Uwagi wymaga fakt, iż ustawodawca w art. 86e ust. 5 p.s.w. expressis verbis nałożył na pracownika uczelni publicznej - nie dłużej niż przez okres przysługiwania praw uczelni - cztery obowiązki. Jest on zobowiązany do zachowania poufności wyników B+R oraz know-how związanego z tymi wynikami. Po drugie, został zobligowany do przekazania uczelni wszystkich posiadanych przez niego informacji, utworów wraz z własnością nośników, na których utwory te utrwalono i doświadczeń technicznych potrzebnych do komercjalizacji. Po trzecie, powinien powstrzymywać się od prowadzenia jakichkolwiek działań zmierzających do wdrażania wyników, wreszcie po czwarte współdziałać w procesie komercjalizacji, w tym w postępowaniach zmierzających do uzyskania praw wyłącznych.

Obowiązki te zostały sformułowane w sposób bardzo ogólny, powinny być uszczegółowione $\mathrm{w}$ regulaminie zarządzania własnością intelektualną oraz w umowie z pracownikiem. Wystarczy zauważyć, że wykładnia literalna obowiązku zachowania wyników $\mathrm{B}+\mathrm{R}$ oraz know-how w poufności przez okres przysługiwania praw uczelni publicznej może powodować np. blokowanie publikowania wyników badań. W przypadku stworzenia wynalazku, na który następnie szkoła wyższa uzyska patent, zachowanie wskazanego w ustawie maksymalnego okresu poufności powodowałoby, że pracownik przez okres trwania prawa wyłącznego, a zatem maksymalnie nawet przez 20 lat nie mógłby rozpowszechniać wyników badań. Co do zasady nie powinno być natomiast przeszkód, by po dokonaniu zgłoszenia patentowego w UPRP ujawnić istotę wynalazku. Podobnie doprecyzowania wymaga jakie informacje, utwory, doświadczenia techniczne niezbędne są uczelni do komercjalizacji. MNiSW stoi na stanowisku, że ich katalog będzie określany biorąc pod uwagę charakter wyników oraz ustalenia stron dokonywane w odniesieniu do konkretnych przypadków. Zaznacza przy tym, że uczelnie oraz twórca powinni mieć na względzie zasady publikacji utworów naukowych oraz obowiązek zachowania poufności wyników B+R, czy związanego z nimi know-how. ${ }^{27}$

Pracownik zobowiązany jest także do przekazania uczelni części środków uzyskanych z komercjalizacji. Zgodnie z art. 86f p.s.w. uczelni publicznej przysługuje $25 \%$ wartości środków uzyskanych przez pracownika z komercjalizacji, obniżonych o nie więcej niż 25\% kosztów bezpośrednio związanych z tą komercjalizacją, które zostały poniesione przez pracownika. Odpowiednio, w przypadku komercjalizacji dokonanej przez uczelnię publiczną albo spółkę celową, pracownikowi przysługuje nie mniej niż 50\% wartości środków uzyskanych z komercjalizacji, obniżonych o nie więcej niż 25\% kosztów bezpośrednio związanych z komercjalizacją, które zostały poniesione przez uczelnię lub spółkę celową. Powyższe prawa przysługują nie 
Transfer wyników pracowniczej twórczości intelektualnej z uczelni do gospodarki...

dłużej niż przez 5 lat od dnia uzyskania pierwszych środków. Należy podkreślić, że wskazane zasady podziału środków z komercjalizacji nie mogą być modyfikowane wolą stron, w tym w drodze umowy, o której mowa w art. 86h p.s.w. W świetle dyspozycji wskazanego przepisu po otrzymaniu od pracownika informacji o wynikach $\mathrm{B}+\mathrm{R}$ oraz o know-how związanym z tymi wynikami, uczelnia publiczna oraz pracownik mogą, w sposób odmienny niż stanowi ustawa, określić w drodze umowy wyłącznie prawa do tych wyników lub sposób i tryb ich komercjalizacji.

Znowelizowane przepisy ustawy akcentują aktywną postawę pracownika w transferze wyników $\mathrm{B}+\mathrm{R}$ do gospodarki. W sytuacji braku działań uczelni albo decyzji o niekomercjalizacji może on przejąć odpowiedzialność za ich skomercjalizowanie. Należy zaaprobować wprowadzenie przez ustawodawcę obowiązku złożenia przez uczelnię publiczną pracownikowi oferty zawarcia umowy o przeniesienie praw do wyników B+R. W przypadku, gdy szkoła wyższa nie posiada opracowanych procedur zarządzania własnością intelektualną, ustalonych struktur zdolnych do dokonania transferu wiedzy, powierzenie pracownikowi komercjalizacji wyników $\mathrm{B}+\mathrm{R}$ może być postrzegane jako korzystne rozwiązanie. Uczelnia nie musi podejmować wysiłków związanych m.in.: z analizą rynku, poszukiwaniem podmiotów zainteresowanych wdrożeniem wyników $\mathrm{B}+\mathrm{R}$, nie ponosi kosztów wynikających z przeprowadzenia procedur ochronnych. Jednocześnie przez okres 5 lat zachowuje prawo do udziału w zyskach. Równolegle pracownik osiąga wyższą pewność, że stworzone przez niego wyniki B+R zostaną zaoferowane podmiotom rynkowym. Zyskuje bowiem prawną możliwość samodzielnego przeprowadzenia procesu komercjalizacji.

Z drugiej strony można przypuszczać, że jedynie osoby posiadające wystarczającą wiedzę z zakresu prawa własności intelektualnej, świadome swoich uprawnień wynikających z przepisów ustawy - Prawo o szkolnictwie wyższym będą monitorować losy zgłoszenia wyniku $\mathrm{B}+\mathrm{R}$, a następnie w przypadku braku decyzji uczelni podejmować działania zmierzające do ich urynkowienia. Zbyt optymistycznym wydaje się jednak założenie, że wszyscy naukowcy wykażą równie przedsiębiorczą postawę. Proces transferu wyników $\mathrm{B}+\mathrm{R}$ łączy w sobie wiele zagadnień $\mathrm{z}$ zakresu prawa, zarządzania, czy ekonomii, wymaga nakładów finansowych, czasu, posiadania kontaktów biznesowych. Powinien być realizowany przy wsparciu specjalistów. Brzmienie znowelizowanych przepisów budzi ryzyko, iż w praktyce pracownik będzie samodzielnie i na własny koszt m.in. przygotowywał ofertę technologiczną, dokonywał wyceny własności intelektualnej, poszukiwał licencjobiorców, czy negocjował umowy. Jednocześnie, pomimo że nie uzyska przy tym pomocy uczelni, będzie zobowiązany przekazać uczelni część osiąganych zysków. Wypada zauważyć, iż wbrew pierwotnym założeniom - przedstawionym w rządowym projekcie ustawy z dnia 17 stycznia 2014 r. - nie wprowadzono zobowiązania centrum transferu technologii lub spółki celowej działających na uczelni publicznej do udzielania pracow- 
nikowi, na jego wniosek, wsparcia w zakresie komercjalizacji stworzonych przez niego wyników $\mathrm{B}+\mathrm{R} .{ }^{28}$

Warto także podkreślić, że zakres podmiotowy regulacji ustawowej - art. 86e-86h p.s.w. - został ograniczony do pracowników uczelni publicznej. Traktując komercjalizację wyników $\mathrm{B}+\mathrm{R}$ jako element strategii zarządzania własnością intelektualną, szkoły wyższe w regulaminie powinny więc ustalić postępowanie w stosunku do wyników $\mathrm{B}+\mathrm{R}$ tworzonych także przez studentów, doktorantów, czy osoby współpracujące z uczelnią na podstawie umowy zlecenia, o dzieło. Należy bowiem zauważyć, że rzadko będą one stanowić przedmiot odrębnych procedur. Powszechną praktyką jest prowadzenie badań i prac rozwojowych w interdyscyplinarnych zespołach składających się z członków posiadających różne stopnie i tytuły naukowe. Określenia wymagają więc prawa oraz obowiązki informacyjne pracowników i innych osób, do których znajduje on zastosowanie. Należy wskazać m.in., w jakiej formie, $w$ jakich terminach zainteresowane strony będą powiadamiane o stworzeniu wyniku $\mathrm{B}+\mathrm{R}$, rozstrzygnięciach w sprawie ich komercjalizacji, czy podjętych działaniach mających na celu urynkowienie uzyskanych w ramach działalności uczelni wyników pracy intelektualnej.

\section{Wstępna ocena znowelizowanych przepisów ustawy - Prawo o szkolnictwie wyższym}

Jak wykazano ze znowelizowanej ustawy - Prawo o szkolnictwie wyższym wynikają wyłącznie wstępne założenia procesu rozpatrywania zgłoszeń pracowniczych wyników pracy intelektualnej, które powinny być uszczegółowione w treści wewnętrznych regulaminów. Obciążenie uczelni budowaniem modelu komercjalizacji wyników B+R można oceniać jako rozwiązanie umożliwiające dostosowanie go do specyfiki każdej szkoły wyższej oraz przejaw poszerzania zakresu samostanowienia instytucji naukowych. Wydaje się jednak, że wciąż jest ono nieuzasadnione. Uczelnie nadal posiadają nieznaczne doświadczenie w komercjalizacji wyników B+R. ${ }^{29}$ Powyższe prowadzi do wniosku, że ustawodawca nowe regulacje oparł na błędnym założeniu, że szkoły wyższe wykazują dostateczne kompetencje, by samodzielnie określić i efektywnie realizować strategie zarządzania własnością intelektualną. Tymczasem, w obszarze polityki $\mathrm{B}+\mathrm{R}$ utrzymywane są utrudnienia od wielu lat identyfikowane przez specjalistów z zakresu prawa, zarządzania, czy ekonomii. ${ }^{30}$ Nadal niezadowalający jest poziom świadomości naukowców, jak i przed-

28 Projekt rządowy z dnia 17 stycznia 2014 r., s. 25.

29 D. Pustuła, Podsumowanie stanu ochrony własności intelektualnej w uczelniach oraz zalecenia dotyczące wdrożenia/usprawnienia zarządzania własnością intelektualną, http://www.uott.uw.edu.pl/images/IPR/podsumowanie_stanu_ochrony_ipr_pustula.pdf (data dostępu: 30.04.2015 r.), s. 7.

30 Por. m.in. W. Orłowski, Komercjalizacja badań naukowych w Polsce. Bariery i możliwości ich przełamania, Warszawa 2013; K.B. Matusiak, J. Guliński, System transferu technologii i komercjalizacji wiedzy w Polsce - siły motoryczne i bariery, Poznań-Łódź-Wrocław-Warszawa 2010. 
siębiorców co do kluczowej roli własności intelektualnej w gospodarce. Pomiędzy przedstawicielami sektora nauki i biznesu wciąż istnieją bariery komunikacyjne. Zasadniczych zmian wymaga struktura finansowania nauki, która w większym stopniu powinna opierać się na środkach pochodzących z sektora prywatnego, postulowane jest również wprowadzenie ulg podatkowych na działalność innowacyjną. Ponadto, poszerzający się zakres obowiązków związanych z komercjalizacją wiedzy powinien wpłynąć na strukturę zatrudnienia w szkołach wyższych. $Z$ jednej strony, konieczne jest kreowanie kompetentnych zespołów obsługujących proces transferu wyników $\mathrm{B}+\mathrm{R}$ z uczelni do gospodarki, z drugiej, pobudzeniu aktywności pracowników w zakresie komercjalizacji, powinno służyć ograniczenie liczby godzin dydaktycznych, obciążeń promotorskich, badawczych. Zaniechanie dalszych reform prowadzić będzie do wzmocnienia pozycji nielicznych uczelni, które już osiągają korzyści z transferu wiedzy, nie wesprze jednak tych jednostek, które dotychczas nie wypracowały efektywnych reguł kooperacji z podmiotami gospodarczymi. Obecnie priorytetem MNiSW powinno stać się opracowanie strategii rozwoju nauki i szkolnictwa wyższego, wyznaczenie celów długoterminowych, które stanowić będą drogowskaz i uzasadnienie działań podejmowanych przez szkoły wyższe. 


\section{TRANSFER OF INTELLECTUAL PROPERTY FROM UNIVERSITY TO ECONOMY}

The main goal of this article is analysis of the legal solutions introduced by the Polish legislature to facilitate transfer of intellectual property between universities and the economy. It discusses the methods of R\&D transfer stemming from the regulations of the Law on Higher Education after the amendment of 11 July 2014. New provisions came into force on 1 October 2014. The author attempts to set a model of the transfer of intellectual property created by the employees from university to the economy.

Słowa kluczowe: transfer własności intelektualnej, komercjalizacja, uczelnia, pracownik, wyniki $\mathrm{B}+\mathrm{R}$

Keywords: transfer of intellectual property, commercialization, university, employee, $R \& D$ 